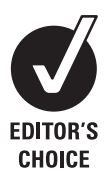

${ }^{1}$ DNA Repair Section, Basic Research Laboratory, Center for Cancer Research, National Cancer Institute, Bethesda, Maryland, USA; ${ }^{2}$ Division of Dermatopharmacology, Department of Dermatology, The Warren Alpert Medical School of Brown University, Providence,

Rhode Island, USA

Correspondence to:

K H Kraemer, DNA Repair Section, Basic Research

Laboratory, Center for Clinical Research, Building 37, Room 4002, MSC 4258, National Cancer Institute, Bethesda, MD 20892, USA; kraemerk@nih.gov

Received 4 March 2008 Revised 16 April 2008 Accepted 1 May 2008 Published Online First 25 June 2008

\title{
Trichothiodystrophy: a systematic review of 112 published cases characterises a wide spectrum of clinical manifestations
}

\author{
S Faghri, ${ }^{1,2}$ D Tamura, ${ }^{1}$ K H Kraemer, ${ }^{1}$ J J DiGiovanna ${ }^{1,2}$
}

\section{ABSTRACT}

Trichothiodystrophy (TTD) is a rare, autosomal recessive disease, characterised by brittle, sulfur deficient hair and multisystem abnormalities. A systematic literature review identified 112 patients ranging from 12 weeks to 47 years of age (median 6 years). In addition to hair abnormalities, common features reported were developmental delay/intellectual impairment (86\%), short stature $(73 \%)$, ichthyosis $(65 \%)$, abnormal characteristics at birth (55\%), ocular abnormalities $(51 \%)$, infections $(46 \%)$, photosensitivity (42\%), maternal pregnancy complications (28\%) and defective DNA repair (37\%). There was high mortality, with 19 deaths under the age of 10 years $(13$ infection related), which is 20 -fold higher compared to the US population. The spectrum of clinical features varied from mild disease with only hair involvement to severe disease with profound developmental defects, recurrent infections and a high mortality at a young age. Abnormal characteristics at birth and pregnancy complications, unrecognised but common features of TTD, suggest a role for DNA repair genes in normal fetal development.

Trichothiodystrophy (TTD) is a rare, autosomal recessive disease, in which patients have brittle, sulphur deficient hair. ${ }^{2}$ When the hair from TTD patients is observed under polarising microscopy, it displays a diagnostic alternating light and dark banding pattern, called "tiger tail banding" ${ }^{4}$ (fig 1). TTD results from mutations in one of several different DNA repair genes $(X P B, X P D$ or $T T D A)^{5}{ }^{6}$ and TTDN1, a gene of unknown function. ${ }^{7}$ Although XPB and XPD mutations are also seen in xeroderma pigmentosum, a disease with a 1000-fold increase in skin cancer, ${ }^{6}{ }^{6-11}$ TTD patients have not been reported to have an increase in cancer.

TTD patients display a wide variety of clinical features, including cutaneous, neurological, and growth abnormalities. As a result, a variety of names have been used to describe the disease. In 1979, Price coined the term "trichothiodystrophy," which encompasses a wide spectrum of neurocutaneous findings, to describe the unifying feature. $^{12}$ The name reflects the brittle, sulfur deficient hair seen in all TTD patients (from Greek, tricho- meaning hair; -thio-, sulfur; -dys-, faulty; -trophy, nourishment). Several acronyms have been used to describe the clinical features of these patients. PIBIDS, ${ }^{13}$ IBIDS $^{14} 15$ and BIDS $^{16}$ describe six features of TTD: Photosensitivity, Ichthyosis, Brittle hair, Intellectual impairment, Decreased fertility, and Short stature. In order to assess the prevalence of the reported clinical features of TTD, we performed an extensive literature review to find all published case reports of patients with TTD. We analysed the frequency of the clinical findings described in an effort to characterise the spectrum of the disease better.

We modelled this review after a similar study on xeroderma pigmentosum. ${ }^{9}$

\section{METHODS}

We developed a standard Excel spreadsheet listing more than 200 clinical and laboratory characteristics. The search was restricted to published information in reports, and no effort was made to obtain unpublished data on the reported patients. This approach results in underreporting of characteristics not noted at the time of publication. However, when reported patients were identifiable as being the same individual in a subsequently reported paper, the data were consolidated. We searched PubMed/Medline, Web of Science, and the references cited in retrieved articles. Search terms were trichothiodystrophy, TTD, Tay syndrome, Pollitt syndrome, PIBIDS, IBIDS, and BIDS.

The most definitive clinical criteria include microscopic examination of hair shafts for tiger tail banding and structural abnormalities and the analysis of hair shaft sulfur content. However, diagnostic criteria for TTD have evolved over the decades since these reports have been published. As a result, some reports included patients with convincing clinical features of TTD and a confirmed DNA repair abnormality, but the clinical workup did not include hair analysis. In order to standardise selection of patients, we chose criteria, which determined whether or not a case report was included. Inclusion criteria were based on having at least two of the four following clinical or laboratory abnormalities: (1) presence of brittle hair and/or hair shaft abnormalities; (2) tiger tail banding with polarised microscopy; (3) decreased sulfur or cystine content of hair; and (4) DNA repair abnormality. While any one of these features is highly suggestive of $\mathrm{TTD}^{3}{ }^{311}{ }^{17}$ we required a minimum of two features to confirm the diagnosis. We chose criteria which we reasoned would allow us to capture reports of most patients with TTD and which were important in forming the basis for the various subtypes which have led to our current understanding of the disease. These criteria were developed in order to provide a uniform approach to inclusion of case reports with varied amounts of information and published over more than 
Figure 1 Microscopic diagnosis of trichothiodystrophy. (Left) Routine microscopic examination of hair from a patient with trichothiodystrophy shows shaft abnormalities of trichoschisis (arrows) and trichorrhexis nodosa-like fraying (arrows). (Right) Under polarising microscopy the hair shafts show a striking alternating dark and light (tiger tail) banding pattern.
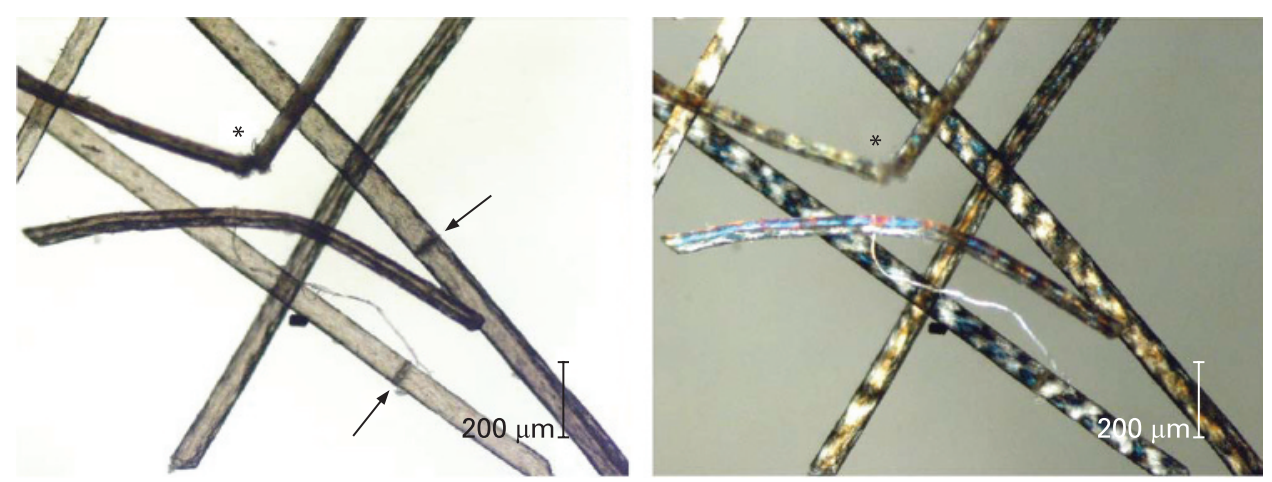

40 years and not to be used as criteria for clinical diagnosis of new patients. ${ }^{3} 4$

In the case of reported siblings with similar clinical features, if one sibling qualified according to the above criteria, then both siblings were included. Patients described collectively as a group were not included when the clinical features could not be traced to individual patients. We did not include cases reported only in meeting proceedings, where the report was not indexed.

We considered intrauterine growth restriction (IUGR) as fetuses specified to have intrauterine growth retardation or intrauterine growth restriction in the report. If this was not stated we used the standard of $<10$ th centile for gestational age at the time of birth based on the criteria specified in Lubchenco. ${ }^{18}$ Low birth weight was stated in the report or was defined as infants or who were $<2500 \mathrm{~g}$ at birth.

\section{RESULTS}

\section{History of trichothiodystrophy}

Vera Price first proposed the name "trichothiodystrophy" in 1979 in the book Haar und Haarkrankheiten. ${ }^{12}$ In 1980, Price ${ }^{17}$ reported two patients with a wide range of clinical features, and associated the low sulfur (cystine) content of the hair with the alternating bright and dark banding with polarised microscopy, now known as tiger tailed banding. This work established specific hair findings as the unifying marker for this neuroectodermal symptom complex, which we now know as TTD.

Before the name TTD was coined in 1979, several papers were published describing cases that are today considered to be the earliest reports of TTD. Some of these papers, however, did not have sufficient hair analysis to meet the inclusion criteria that we chose for this paper. ${ }^{19-21}$ The earliest paper that we included in this study is from Pollitt ${ }^{22}$ in 1968, which described two severely affected siblings with brittle, sulphur deficient hair, as well as intellectual and growth retardation. This report led to the name Pollitt syndrome. In 1970, Brown ${ }^{23}$ described alternating birefringence in the hair viewed under polarised microscopy in a 4-year-old girl with brittle hair and normal intelligence. Tay, ${ }^{24}$ in 1971, reported three siblings in Singapore with brittle hair, mental deficiency and growth retardation, who also had non-bullous congenital ichthyosiform erythroderma. Tay suggested an autosomal recessive pattern of inheritance. Tay's 1971 report did not, however, include sufficient hair analysis to meet the inclusion criteria for this analysis. In 1974, Jackson ${ }^{25}$ described decreased fertility and autosomal recessive inheritance in an Amish kindred with brittle hair, intellectual impairment and short stature. Two index cases were sufficiently described to be included in this analysis.
Jackson's report led to the name "Amish brittle hair brain syndrome". As a result of these similar clinical descriptions, the acronym BIDS (Brittle hair, Intellectual impairment, Decreased fertility and Short stature) was suggested in $1976 .{ }^{16}$ Subsequently, the additional presence of ichthyosis led to the acronym IBIDS. ${ }^{14}{ }^{15}$ Unlike some later cases of TTD with ichthyosis, it has been suggested that Tay syndrome specifically refers to the presence of congenital ichthyosis in addition to BIDS. ${ }^{26}$

Two siblings from Sabinas, Mexico were reported in $1976^{27}$ as having brittle hair, developmental delay, and normal stature. This report, in conjunction with a report ${ }^{28}$ of a group of 11 additional TTD cases from Sabinas, led to the name Sabinas syndrome in 1981, which refers to the presence of hair and nail abnormalities in association with mental retardation. The 1981 report $^{28}$ was not included in this review because the patients were described as a general group and not individually.

The addition of photosensitivity to the acronym IBIDS (resulting in PIBIDS) was recommended in 1983 by Crovato. ${ }^{13}$ There was also some debate as to whether TTD was in fact a single entity, due to the various presentations of this neuroectodermal disorder. ${ }^{29}$ In 1988, Chapmann reported a patient and recommended the addition of skeletal abnormalities instead of photosensitivity to the acronym, resulting in SIBIDS. ${ }^{30}$ The patient described in this report did not meet our inclusion criteria for this analysis.

In 1985, Van Neste ${ }^{31}$ reported defective DNA excision repair in ultraviolet (UV) exposed lymphocytes from a TTD patient. The first such gene mutation was identified the next year, ${ }^{32}$ when cells from four patients with TTD were found to have cellular UV hypersensitivity, very low levels of unscheduled DNA synthesis, and characteristics of the XP-D complementation group. Despite some patients having the same gene defects seen in xeroderma pigmentosum (XPB and XPD), patients with TTD do not have an increased incidence of skin cancers. ${ }^{211}$ In 1993, patient TTD1BR was reported to have a new DNA repair complementation group, called TTD-A. ${ }^{33}$ A second patient with TTD-A has since been reported. ${ }^{34}$ The TTD-A gene (called GTF2H5) was identified in 2004. ${ }^{35}$ The recently discovered TTDN1 gene with unknown function was described in association with non-photosensitive patients. ${ }^{7}$

To date, four genes have been identified as causing TTD: $X P D, X P B, T T D A$, and TTDN1.732 3336

\section{Cases reports included in this study}

A total of 94 articles were found that met our inclusion criteria for TTD case reports. The articles were published from 1968 to

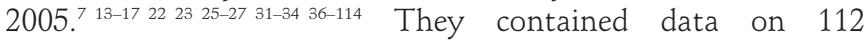
patients. The reported cases met at least two of the four entry 
Table 1 Distribution of patient location or origin for reported trichothiodystrophy patients $(n=112)$

\begin{tabular}{|c|c|}
\hline Author location* & $\begin{array}{l}\text { Patients } \\
\text { No. (\%) }\end{array}$ \\
\hline Italy & $27(23)$ \\
\hline USA & $19(16)$ \\
\hline UK & $18(16)$ \\
\hline France & $12(11)$ \\
\hline Germany & $3(3)$ \\
\hline Canada & $4(4)$ \\
\hline Morocco & $4(4)$ \\
\hline Turkey & $4(4)$ \\
\hline Switzerland & $4(4)$ \\
\hline Other $\dagger$ & $17(15)$ \\
\hline Total & $112(100)$ \\
\hline
\end{tabular}

criteria, as follows: $96 \%$ (108 cases) had brittle hair or hair shaft abnormalities; there were $73 \%$ (82 cases) with tiger tail banding of the hair with polarised microscopy; $70 \%$ (78 cases) had decreased sulfur or cystine content of their hair; $37 \%$ (41 cases) had a DNA repair abnormality reported; four patients were included based on having brittle hair and a diagnosed sibling with TTD. 859098

Table 1 shows patient location and origin. As these data were only reported for 50 patients, the author's location was used for the remaining 62 patients, assuming that the patients were from the same location as the author. Patients/authors were reported from 20 countries from all over the world, including Europe, North and South America, Africa, Asia and Australia. The greatest numbers of reports were from Italy (23\%), the USA $(16 \%)$, and the UK (16\%).

\section{Mode of inheritance, demographics, age, and survival}

Gender was reported for 105 patients in this review, and consisted of 54 males (51\%) and 51 females (49\%). TTD is an

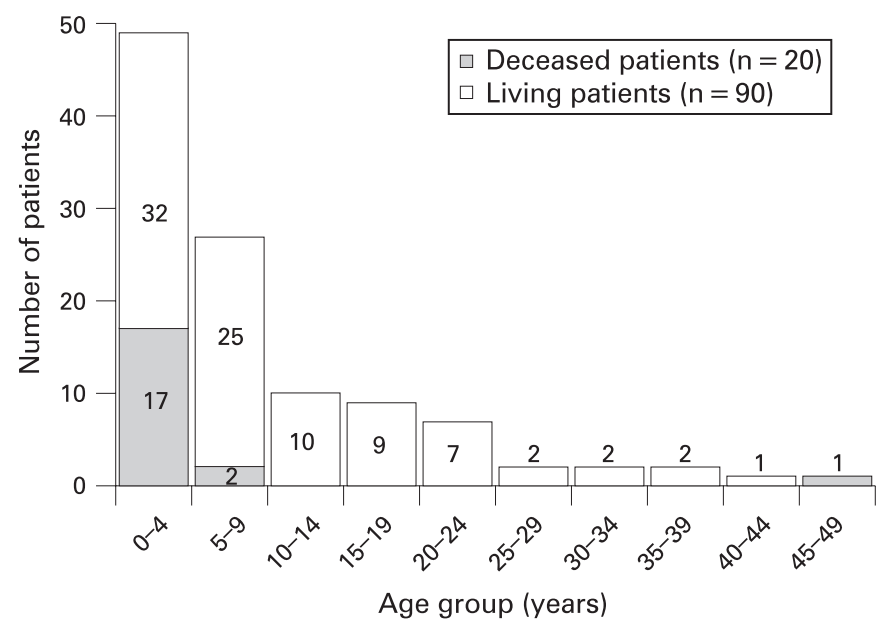

Figure 2 Age at last report in trichothiodystrophy (TTD) patients $(n=110)$. The number in each bar indicates the number of patients reported in the indicated age group among the 90 reported living TTD patients. The shaded portion of the bar indicates the number of patients who died in the indicated age range among the 20 reported deceased TTD patients. autosomal recessive disease, and is therefore expected to have an equal distribution between males and females. There was one report $^{65}$ suggesting the possibility of $\mathrm{X}$-linked inheritance in a TTD patient with urea cycle dysfunction.

Age was reported for 110 of the 112 patients included in this study (fig 2). The age at last report ranged from 12 weeks to 47 years, with a median of 6 years. There was a median age of 6.5 years for males and 6 years for females. The ages ranged from 12 weeks to 44 years for males and 5 months to 47 years for females.

Twenty patients were reported as deceased, ranging in age from 12 weeks to 47 years (fig 2). All but one of these patients were under 10 years old and the median age at death was 3 years. The cause of death was pneumonia or other infection (especially sepsis) for 13 of these patients (fig 3)..$^{40} 416374859091949899107$ One additional patient ${ }^{85}$ died at 12 months after developing a fever, despite antibiotic use. The remaining patients died of drowning, ${ }^{62}$ cachexia and dehydration, ${ }^{98}$ respiratory failure, ${ }^{46}$ or a sudden or unexpected death. ${ }^{32} 68$ One patient ${ }^{32}$ who died suddenly had a history of frequent hospitalisations for respiratory and gastrointestinal illnesses, and thus may have also died from infectious complications. The oldest patient ${ }^{56}$ died at 47 years after presenting with generalised oedema and urinary retention, which progressed to coma. Cause of death was not reported for one patient. ${ }^{111}$

Kaplan-Meier analysis of the reported deaths indicated that at age 3 years there was $10.7 \%$ probability of reported death, and by age 9 years the probability had increased to $21.3 \%$. This represents an approximately 20 -fold higher mortality compared to the US general population. While we would expect that unusual and severe outcomes might be preferentially reported, this large number of deaths at a young age highlights the potential severity of TTD in the neonatal and early childhood period.

Recessively inherited disorders occur more commonly in populations where consanguinity is frequent. This literature review revealed $17 \%$ consanguinity, $49 \%$ non-consanguinity

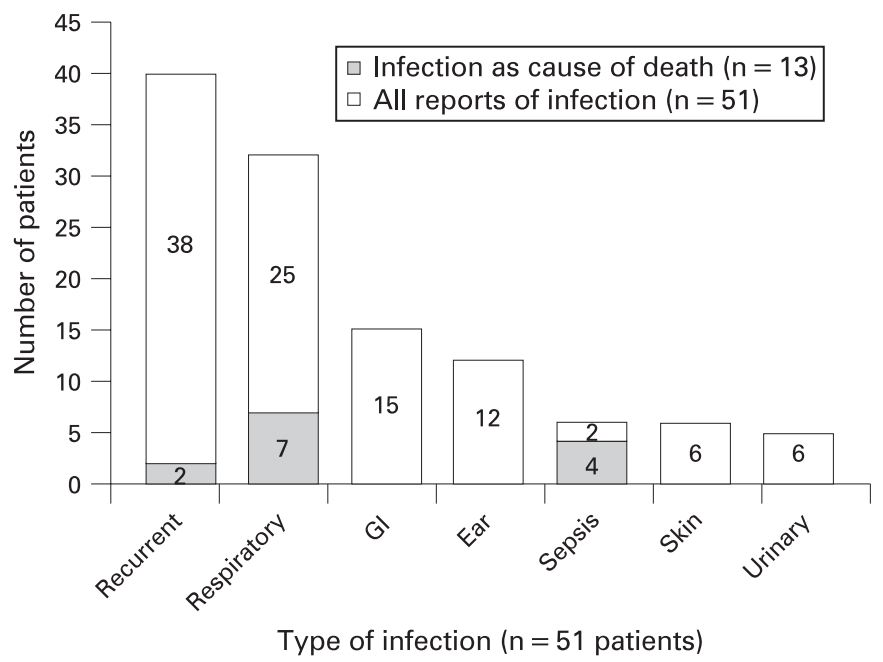

Figure 3 Infections reported $(\mathrm{n}=51)$ in trichothiodystrophy patients. The number in each bar indicates the number of patients reported with the indicated type of infection among the 51 reported patients. A patient may have more than one reported infection. The shaded portion of the bar indicates the number of patients with the indicated type of infection as the cause of death among the 13 cases who died of infection. Aetiologies of infections included bacterial, fungal and viral. Gl, gastrointestinal. 


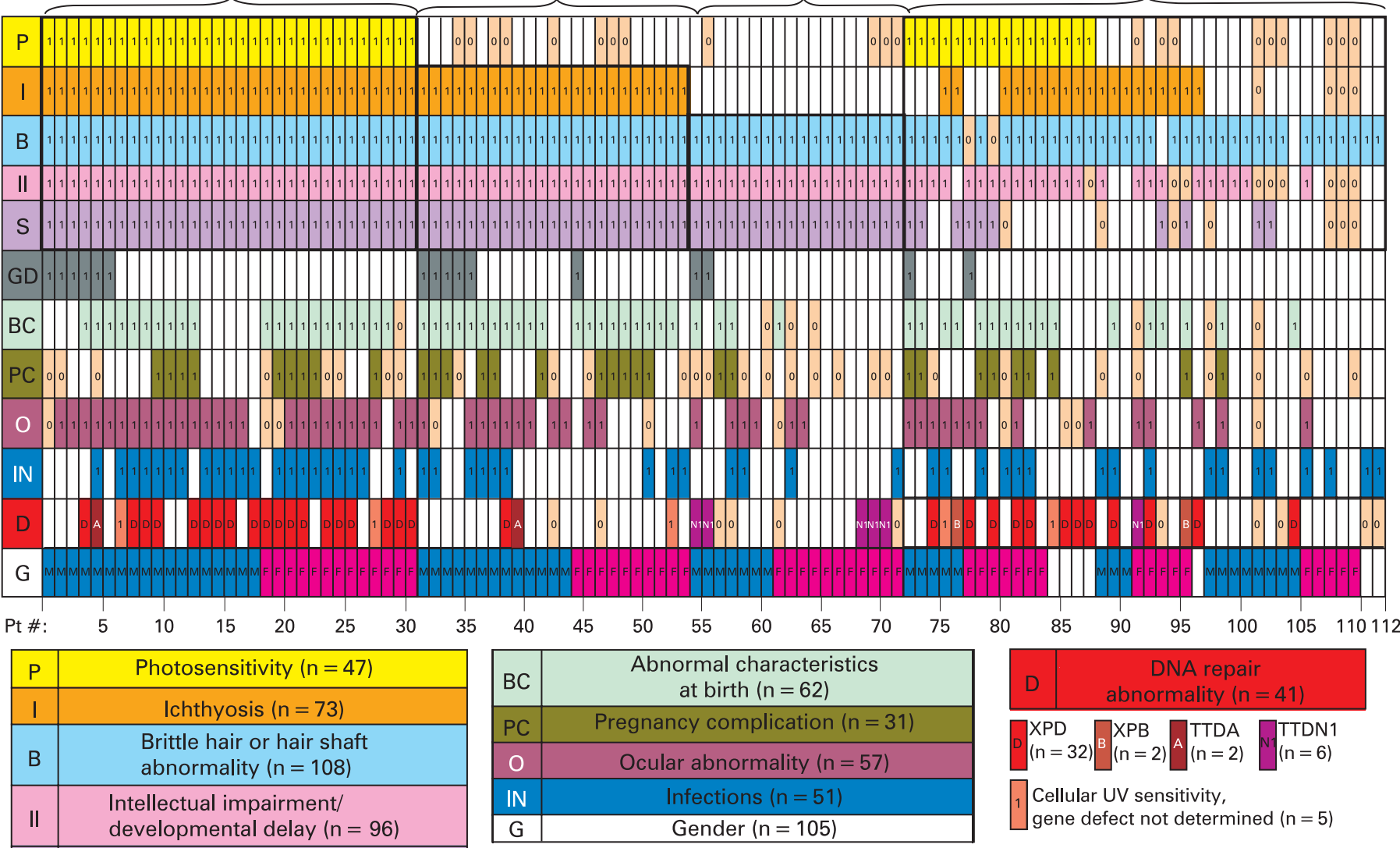

S Short stature $(n=82)$

GD Gonadal dysgenesis $(n=16)$

Figure 4 A clinical array of features reported in the literature on 112 trichothiodystrophy patients. Each column of rectangles represents clinical features of one reported patient. Presence or absence of each feature is indicated in each rectangle of a column. Abnormal clinical features reported are indicated by " 1 " in a coloured rectangle. Normal reported features are indicated by " 0 " in a tan rectangle. Unreported features are blank. The rows represent $P$ (yellow) — photosensitivity $(n=47$ cases); I (orange)—ichthyosis $(n=73$ cases); $B$ (powder blue)—brittle hair or hair shaft abnormality ( $\mathrm{n}=108$ ); II (pink) —intellectual impairment ( $\mathrm{n}=96$ cases); GD (grey) —gonadal dysgenesis ( $\mathrm{n}=16$ cases); $\mathrm{BC}$ (light green) —abnormal birth characteristics ( $\mathrm{n}=62$ cases); PC (dark green) — pregnancy complications ( $\mathrm{n}=31$ pregnancies); 0 (maroon)—ocular abnormality ( $\mathrm{n}=57$ cases); IN (royal blue) —infections ( $n=51$ patients); $D$ (red)—DNA repair abnormality $(n=41)$; $D$ in red rectangle $-X P D(n=32$ cases); $B$ in striped red rectangle $-X P B(\mathrm{n}=2$ cases); $A$ in striped red rectangle $-T T D A(n=2) ; N$ in striped pink rectangle $-T T D N 1$ ( $n=6$ cases); I in red rectangle-cellular ultraviolet (UV) hypersensitivity, gene not determined $(n=5) ; G$-gender ( $n=105$ patients); blue rectangles—males $(n=54$ cases); pink rectangles -females $(n=51$ cases). Patients whose clinical features fulfil the criteria for PIBIDS (28\%), IBIDS (20\%), BIDS (16\%) and those that do not (OTHER) (36\%), are grouped by bold outline (decreased fertility is ignored in this grouping due to inability to assess in children.)

and $36 \%$ unreported. None of the parents were reported to have TTD. Data were given on the presence or absence of siblings in 80 patients. Thirty-seven patients have a sibling who is also described as a patient in this review (represents 18 families for these 37 patients). The total number of siblings ranged from 0 to 9 , with a median of 1 .

\section{Spectrum of clinical abnormalities reported in TTD patients}

Figure 4 displays the common clinical features reported for each patient in the format of a clinical array. Each column represents one patient, with each clinical feature indicated as present, absent, or not mentioned in the report. The columns are grouped to facilitate identification of patients by gender with features of PIBI(D)S (28\%), IBI(D)S (20\%), BI(D)S (16\%) and those that did not fit these categories (36\%). Because decreased fertility (D) is age dependent and difficult to quantify from these reports, this feature was not included in this figure. Instead, we have indicated patients with gonadal dysgenesis.
Arraying patients in this format highlights those who fit the clinical criteria defined by these acronyms and those where the acronym inadequately describes the clinical presentation. Other commonly reported clinical features are also shown in this figure, including abnormal characteristics at birth, pregnancy complications, ocular abnormalities, and infections. DNA repair abnormalities that were identified are also shown.

\section{Skin findings}

Seventy-nine per cent of the 112 reported TTD patients had skin abnormalities (table 2). Seven patients were reported to have normal skin and 16 reports did not include any skin descriptions. The most frequently reported skin finding was ichthyosis (65\%) (table 2, fig 4). Of the 73 patients with ichthyosis, 27 had collodion membrane at birth.

Ten patients were reported to have lamellar ichthyosis and six of these had collodion membrane at birth. Ichthyosis was seen in almost all age groups. 
Table 2 Frequency of skin abnormalities reported $(\mathrm{n}=89)$ in trichothiodystrophy patients

\begin{tabular}{lc}
\hline & $\begin{array}{c}\text { Patients } \\
\text { No. (\%) }\end{array}$ \\
\hline Skin abnormality & $89(79)$ \\
Ichthyosis (all forms) & $73(65)$ \\
Lamellar ichthyosis & $10(9)$ \\
Photosensitivity & $47(42)$ \\
Eczema & $9(8)$ \\
Freckles & $8(7)$ \\
Dry skin, NoS & $7(6)$ \\
Erythroderma & $5(4)$ \\
Other* & $20(18)$ \\
Normal skin; not reported & $7(6) ; 16(14)$ \\
Total & $112(100)$ \\
\hline NOS, not otherwise specified. & \\
*“Other" refers to telangiectasia (5 patients), pruritis (4), folliculitis \\
(3), cheilitis (3), follicular keratosis (3), hypohidrosis (3), \\
haemangioma of skin (2), poikiloderma (2).
\end{tabular}

The second most frequent skin finding reported was photosensitivity (42\%).

Seventy per cent of the 112 patients in this study had photosensitivity and/or ichthyosis (28\% of all patients had both photosensitivity and ichthyosis) (fig 4). Twenty-seven of the 47 patients with photosensitivity were reported as having mutations in XPD, one in XPB, and one in TTDA (table 3, fig 4). Four patients were not assigned to a complementation group, but were found to have cellular UV hypersensitivity. ${ }^{31} 59100$ Although the XPD gene mutation has been reported to be associated with the clinical finding of photosensitivity, there was one case of a TTD patient ${ }^{112}$ with an XPD gene mutation reported as non-photosensitive. Other cutaneous findings include dry skin (21\%), eczema (8\%), and freckles $(7 \%)$. Freckling is generally associated with XP and not TTD. Two of the TTD patients ${ }^{45}$ with freckles were reported to also have $\mathrm{XP}$ (the XP/TTD complex), and one of them had a skin cancer. Six other patients with freckles were not reported to have skin cancer. ${ }^{32} 415881$ One additional TTD patient ${ }^{54}$ had a well differentiated, invasive squamous carcinoma on his nose, but was not reported to have freckles. Other more rare skin findings include two reports of haemangioma ${ }^{84} 105$ and three reports of cheilitis. ${ }^{13} 2265$

Nail abnormalities (table 4) were reported in 70 patients $(63 \%)$. The most frequent nail abnormality reported was onychodystrophy in 41 patients (37\%), which included dysplasia, dystrophic nails, thickening or yellow discoloration. Other common nail findings were brittle nails (14\%), hypoplasia $(13 \%)$, and koilonychia (12\%).

\section{Hair and nail findings}

Hair abnormalities were reported in all 112 patients (table 4, fig 4). They are a defining feature of TTD, and were part of the inclusion criteria. The most frequent hair findings were brittle hair or hair shaft abnormalities (96\%), tiger tail banding (73\%), and decreased sulfur or cystine (71\%). Two patients with the XP/TTD complex were reported not to have brittle hair, but did have decreased sulfur, tiger tail banding with polarised microscopy, and XPD mutations. ${ }^{45}$ Sparse hair (48\%) and alopecia (39\%) were also commonly reported. Eight patients had hair loss with fever or infection. ${ }^{5058596887107}$ Although TTD is usually associated with short hair (due to its brittle and easily breakable nature), there were also five reports of patients with
Table 3 Cellular studies reported $(n=58)$ in trichothiodystrophy patients

\begin{tabular}{lc}
\hline Gene defect & $\begin{array}{c}\text { Patients } \\
\text { No. (\%) }\end{array}$ \\
\hline Reduced DNA repair & $41(37)$ \\
XPD & $32(29)$ \\
XPB & $2(2)$ \\
TTD-A & $2(2)$ \\
TTDN1 & $6(5)$ \\
Normal DNA repair; not reported & $11(10) ; 54(48)$ \\
Total & $112(100)$ \\
\hline TTD, trichothiodystrophy; XP, xeroderma pigmentosum.
\end{tabular}

long or normal length hair, ${ }^{36} 384578115$ including $1 \mathrm{XP} / \mathrm{TTD}$ patient. ${ }^{45}$

\section{Neurologic findings}

Neurologic abnormalities were reported in 100 patients (table 5, fig 4). Developmental delay or intellectual impairment was reported in $86 \%$ of patients, and spanned all age groups. These usually presented as failing to achieve developmental milestones, such as sitting, walking, or talking, on time. ${ }^{112}$ Eleven of the 16 patients who were not reported to have developmental delay or intellectual impairment were $<5$ years old. ${ }^{23} 384661788490107$ Of the patients with developmental delay or intellectual impairment, 41 also had impaired motor control or psychomotor retardation. Seventeen of the patients with neurologic abnormalities were also described as having notably sociable or outgoing behaviour. This outgoing, sociable interaction is also a feature of patients with Cockayne syndrome (CS). ${ }^{11}$

Intelligence quotient (IO) was given for 21 patients. These tests included Terman-Merrill (three patients, IO range 2540), ${ }^{89}$ Wechsler Intelligence Scale for Children (two patients, IO range 45-89), ${ }^{25}{ }^{39}$ Stanford-Binet (three patients, IQ range 3279) ${ }^{14} 1593$ and not specified or other exam (such as Leiter scale and Ruth Griffiths test) (13 patients, IO range 3488). ${ }^{1727376064697176777983}$ As a result, an average value could not be determined. Ichthyosis was closely linked to developmental delay since 67 (92\%) of 73 patients reported with ichthyosis were also reported to have developmental delay.

Other abnormal neurologic findings described include microcephaly (50\%), abnormal gait (26\%), and increased deep tendon reflexes (13\%). Audiologic examination was performed in 25 patients, and found normal hearing in 20 and sensorineural hearing loss in the other five. Nine patients were reported to have high pitched/raspy voice ${ }^{14} 175773767782$ and one patient had dysphonia. ${ }^{40}$ Six patients were reported to have attention deficit or hyperactivity $^{22} 2750698189$ and three patients as autistic-like. ${ }^{75} 81101$

Neuroimaging abnormalities were given in $23 \%$ of patients. The most common findings were dysmyelination (14\%), cerebellar atrophy (4\%), and dilated ventricles (4\%), which are similar to features found in CS. ${ }^{11}$ One patient had a progressive encephalopathy with ataxia and a gradual deterioration of previously acquired skills. ${ }^{63}$ In one patient, ${ }^{70}$ an attack of measles at age 4 years was reported to be followed by general disability, and according to his mother a regression of development, but subsequent to that had slow progress with no further degeneration. Another patient, ${ }^{56}$ however, did not change during a 30 year period. The electroencephalogram (EEG) findings were reported in 27 patients, of which 14 were normal and 13 were abnormal (four of these patients had seizures). ${ }^{25} 60113$ 
Table 4 Frequency of hair and nail features $(n=112)$ in reported trichothiodystrophy patients

\begin{tabular}{lc}
\hline & $\begin{array}{c}\text { Patients } \\
\text { No. (\%) }\end{array}$ \\
\hline Hair feature & $112(100)$ \\
Brittle hair or hair shaft abnormality & $108(96)$ \\
Brittle hair & $98(88)$ \\
Hair shaft abnormality & $76(68)$ \\
Tiger tail & $82(73)$ \\
Decreased sulfur or cystine & $79(71)$ \\
Sparse hair & $54(48)$ \\
Alopecia & $44(39)$ \\
Hair loss with fever or infection & $8(7)$ \\
Dry hair & $24(21)$ \\
Fine hair & $16(14)$ \\
Slow growing hair & $8(7)$ \\
Long hair & $5(4)$ \\
Nail feature & $70(63)$ \\
Onychodystrophy* & $41(37)$ \\
Brittle nails & $16(14)$ \\
Hypoplasia & $15(13)$ \\
Koilonychia & $13(12)$ \\
Splitting (onychoschizia); peeling & $8(7)$ \\
Ridging & $7(6)$ \\
Other† & $3(3)$ \\
Normal nails; not reported & $14(13) ; 28(25)$ \\
Total & $112(100)$ \\
\hline
\end{tabular}

*We collated reports of dysplasia, dystrophic nails, thickening and yellow discoloration as onychodystrophy.

$\dagger$ Slow growing nails (2 patients) and soft nails (1).

Five cases reported "mild TTD", in which the patients had involvement of only hair, skin or nails. ${ }^{23} 373884$ Two of these patients ${ }^{38}$ had abnormal nails and one $e^{84}$ had dry skin, but none had the neurologic abnormalities seen in many TTD patients. No gene defect was reported for these patients.

Facial dysmorphism was reported in $66 \%$ of patients (table 6). These included microcephaly $(50 \%)$, large or protruding ears $(30 \%)$, and micrognathia (29\%). As in CS, there have been descriptions of TTD patients with aged (9\%) or "bird-like" appearances (8\%).

\section{Growth abnormalities}

Eighty-one per cent of patients were reported to have either low height and/or weight (which includes six patients described as having "growth retardation") (fig 4). Sixty-one per cent of patients had both short stature and low weight or poor weight gain. An additional 13 patients ${ }^{27} 455660$ had short stature with either normal or unreported weight. Six patients had normal height and weight. ${ }^{27} 38628497113$

\section{Gonadal dysgenesis}

Sixteen patients (14\%) had sexual/reproductive abnormalities reported (fig 4). Thirteen of these patients had hypogonadism $^{15} 264045567176778689101$ of which two were females ${ }^{40} 56$ and nine had cryptorchidism. ${ }^{15} 2526405873767786$ Two cases reported delayed pubertal development. ${ }^{7011}$ Additional genitourinary abnormalities in females included poor sexual maturation ${ }^{142}$ and partial panhypopituitarism. ${ }^{114}$

\section{Pregnancy and birth characteristics}

Thirty-four patients overall were reported to have parents in good health. When the TTD patients were born, the median
Table 5 Frequency of neurologic features reported $(n=100)$ in trichothiodystrophy patients

\begin{tabular}{lc}
\hline & Patients \\
& No. (\%) \\
\hline Developmental delay or intellectual impairment & $96(86 \%)$ \\
Intellectual impairment & $84(75 \%)$ \\
Developmental delay & $76(68 \%)$ \\
Impaired motor control/psychomotor retardation & $41(37 \%)$ \\
Sociable/outgoing behaviour & $17(15 \%)$ \\
Clinical neurologic findings & $84(75 \%)$ \\
Microcephaly & $46(50 \%)$ \\
Abnormal gait/ataxia & $29(26 \%)$ \\
Audiologic exam performed: normal hearing; sensorineural & $20(18 \%) ; 5(4 \%)$ \\
hearing loss & \\
Abnormal deep tendon reflex: increased; decreased & $15(13 \%) ; 1(1 \%)$ \\
Electroencephalogram: normal; abnormal & $14(13 \%) ; 13(12 \%)$ \\
Abnormal muscle tone: increased; diminished & $8(7 \%) ; 11(10 \%)$ \\
Nerve conduction velocity performed: normal; slow & $9(8 \%) ; 3(3 \%)$ \\
Spasticity & $11(10 \%)$ \\
Intention tremor & $8(7 \%)$ \\
Seizure & $7(6 \%)$ \\
Paresis/plegia & $6(5 \%)$ \\
Dysarthria & $5(4 \%)$ \\
Pyramidal signs & $5(4 \%)$ \\
Peripheral neuropathy & $2(2 \%)$ \\
Neuroimaging abnormality & $26(23 \%)$ \\
Dysmyelination & $16(14 \%)$ \\
Atrophy: cerebellar; cortical & $5(4 \%) ; 3(3 \%)$ \\
Dilated ventricles & $4(4 \%)$ \\
Calcifications & $2(2 \%)$ \\
Other* & $5(4 \%)$ \\
No abnormality reported & $12(11 \%)$ \\
Total & $112(100 \%)$ \\
\hline
\end{tabular}

*"Other" refers to partial agenesis of corpus callosum (1 patient), slight widening of subarachnoid spaces (1), thin corpus callosum (1), cerebral infarction (1), focal grey matter heterotopia and acute necrotising encephalopathy (1).

reported maternal age was 25 years (based on 16 patients) and the median reported paternal age was 27 years (14 patients).

Two previously unrecognised findings not commonly associated with TTD are abnormal characteristics at birth (fig 5) and pregnancy complications (fig 6). Abnormal characteristics at birth were reported in 62 patients (55\%) (fig 5). The most common finding was low birth weight (defined as birth weight $<2500 \mathrm{~g}$ or specified as being low) which was reported in 41 patients (37\%). In the USA for the year $20058.2 \%$ of infants were born with low birth weight $(<2500 \mathrm{~g})^{116}$ The actual birth weight was specified for 53 patients and ranged from $0.94-4 \mathrm{~kg}$, with a median of $2.2 \mathrm{~kg}$. This is much smaller than the median birth weight of 3.0-3.5 kg of infants born between 37-40 weeks of gestation in the US general population. ${ }^{116}$ Five additional cases specified low birth weight without giving a value. ${ }^{14} 8598107$ The length of gestation was reported in 53 patients and ranged from 25-42 weeks. The median gestational age for all reported cases was 37 weeks. Thirty-two of these patients (29\%) were born prematurely ( $<37$ weeks). Apgar scores were given for eight patients, two of which ${ }^{7100}$ were $<7$ at 5 min, indicating perinatal asphyxia. Twenty-nine of the infants $(26 \%)$ had a collodion membrane at birth. Twenty-seven of these also were reported to develop ichthyosis (six of which were lamellar ichthyosis). For the two patients with collodion presentation not reported to have icthyosis, one paper had very limited information about the patient, ${ }^{46}$ and the other paper only reports that the patient later had dry scaly skin. ${ }^{76}$ Thirteen patients had brittle or abnormal hair. There were 14 patients 
Table 6 Facial dysmorphism reported $(n=74)$ in trichothiodystrophy patients

\begin{tabular}{lc}
\hline & $\begin{array}{c}\text { Patients } \\
\text { No. (\%) }\end{array}$ \\
\hline Facial dysmorphism & $74(66)$ \\
Microcephaly & $56(50)$ \\
Large or protruding ears & $34(30)$ \\
Micrognathia & $33(29)$ \\
Aged appearance & $10(9)$ \\
"Bird-like" & $9(8)$ \\
High arched palate & $8(7)$ \\
Epicanthal fold & $8(7)$ \\
Frontal bossing & $5(4)$ \\
Hypotelorism; hypertelorism & $6(5) ; 3(3)$ \\
Craniosynostosis & $1(1)$ \\
Not reported & $38(34)$ \\
Total & $112(100)$ \\
\hline
\end{tabular}

(13\%) reported to have short birth length 22344045687081859899106 and eight patients $(7 \%)$ to have small birth head circumference. $^{40859899106}$ Values for birth length were given for 18 patients, ranging from $36-51 \mathrm{~cm}$, with a median of $46 \mathrm{~cm}$. Values for birth head circumference were given for 10 patients, ranging from $28-35 \mathrm{~cm}$, with a median of $31 \mathrm{~cm}$. Five additional patients were specified to have low birth length and head circumference, but no value was given. ${ }^{85}{ }^{98}$ Cryptorchidism was reported for nine $(17 \%)$ of the boys. Congenital cataracts were identified in eight $(7 \%)$ of the reported cases. This is also a feature of CS and is greatly elevated compared to the frequency of $1-2.5$ per 10000 live born infants ${ }^{117}$ in the general population. In addition, five patients were described as having infections (including respiratory infections) in the neonatal period (fig 3).

The course of pregnancy refers to the pregnancy of the patient's mother, when she was pregnant with the reported TTD case (fig 6). There was no information reported for 52 $(48 \%)$ of the pregnancies. This is not surprising since many of the reports were in the dermatologic literature. In 29 of the 112 cases $(26 \%)$ the pregnancy was described as uncomplicated; however, eight of these neonates had abnormal characteristics at birth. Pregnancy complications were reported in 31 cases $(28 \%)$ and the TTD neonates from these pregnancies all had abnormal characteristics at birth (fig 5). The reports contained information on gestational age at birth and birth weight of the newborns. Twenty-three patients (21\%) had IUGR stated in the report or alternatively, which we determined as low weight for the gestational age at birth. ${ }^{18}$ Pre-eclampsia was reported in eight pregnancies (7\%)22 32396894100105115 and eclampsia or seizures in three. ${ }^{17}{ }^{63} 108$ There did not seem to be a correlation between IUGR and pre-eclampsia, as only three cases had both. $^{32} 68100$ In addition, one pregnancy ${ }^{85}$ was reported as having an abnormal prenatal screening test (elevated maternal serum $\alpha$ fetoprotein). There were 13 cases of caesarean section and four cases of breech presentation. ${ }^{57} 7399108$ The caesarean sections were performed secondary to both maternal indications (five cases) and fetal indications (eight cases). The maternal indications were pre-eclampsia (three cases), ${ }^{32} 39105$ toxaemia and seizures (one) ${ }^{63}$ and abruptio placenta (one). ${ }^{26}$ Fetal indications included IUGR (four cases), ${ }^{40} 75$ breech presentation (two), ${ }^{57} 99$ fetal distress (one) ${ }^{69}$ and fetal asphyxia (one). ${ }^{74}$ Other pregnancy complications reported were bleeding (two cases), oligohydramnios (one) and placental abnormality (one). Pregnancy loss was reported in five pregnancies of mothers who also had a child with TTD. One loss was an intrauterine fetal demise at

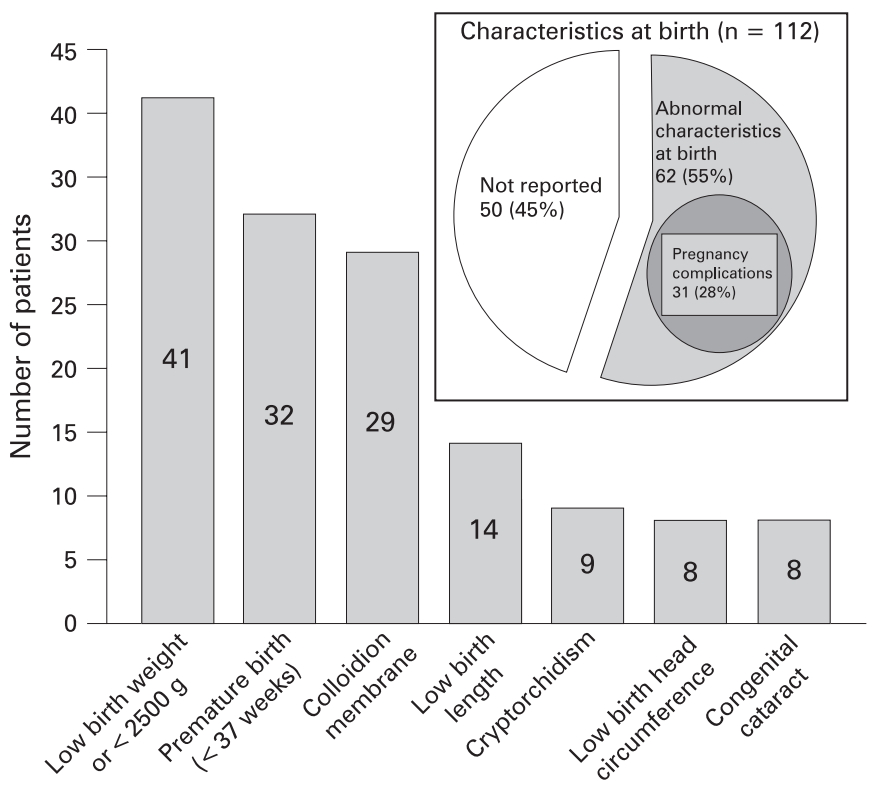

Abnormal birth characteristic ( $n=62$ patients)

Figure 5 Abnormal characteristics at birth reported $(n=62)$ in trichothiodystrophy patients. The number in each bar indicates the number of patients reported with the indicated birth characteristic among the 62 reported patients. A patient may have more than one abnormal birth characteristic. The inset shows the proportion of the 112 cases reporting abnormal birth characteristics, pregnancy complications or both.

19 weeks 4 days of gestation; the other four losses were described as spontaneous abortions or miscarriage with no gestational age provided. ${ }^{32} 90$ 97-99

In addition to the patients described in this review, five additional patients were diagnosed with TTD in utero by prenatal diagnostic methods. Prenatal diagnosis was reported in families with a previous child diagnosed with TTD. None of the pregnancies with the affected fetuses went to term. Methods of prenatal diagnosis reported included fetal hair biopsy and DNA repair measurements..$^{90} 98100118119$ One study measured UV induced unscheduled DNA synthesis (UDS) in cultivated amniotic fluid cells at 17 weeks gestation. After a therapeutic abortion, the diagnosis was confirmed by severe DNA excision repair defect in fetal skin fibroblasts. While UV induced UDS cannot differentiate among different DNA repair abnormalities, ${ }^{11}$ this family had a previous child with diagnosed TTD. ${ }^{100}$ During a later pregnancy in the same reported family, prenatal diagnosis was made by chorionic villus sampling at 9 weeks gestation and finding quantitatively normal DNA excision repair. ${ }^{119}$ Another study that same year looked at two pregnancies using DNA repair defects in trophoblasts (at 9 weeks gestation) or amniotic cells (at 21 weeks gestation) and then further supported by fetal hair analysis. ${ }^{98}$ Alkaline comet assay (single cell gel electrophoresis assay) was performed on amniotic or chorionic villus cells to diagnose a fetus as having TTD. ${ }^{118}$ A later study used endoscopically guided fetal eyebrow biopsy during the second trimester, and found tiger tail banding under polarised light..$^{90}$

\section{Ocular abnormalities and infection}

Ocular abnormalities were reported in $51 \%$ of patients (fig 7 ). Thirty-two of these patients had cataracts, of which 20 were specified as bilateral and eight as congenital (fig 5). The median 


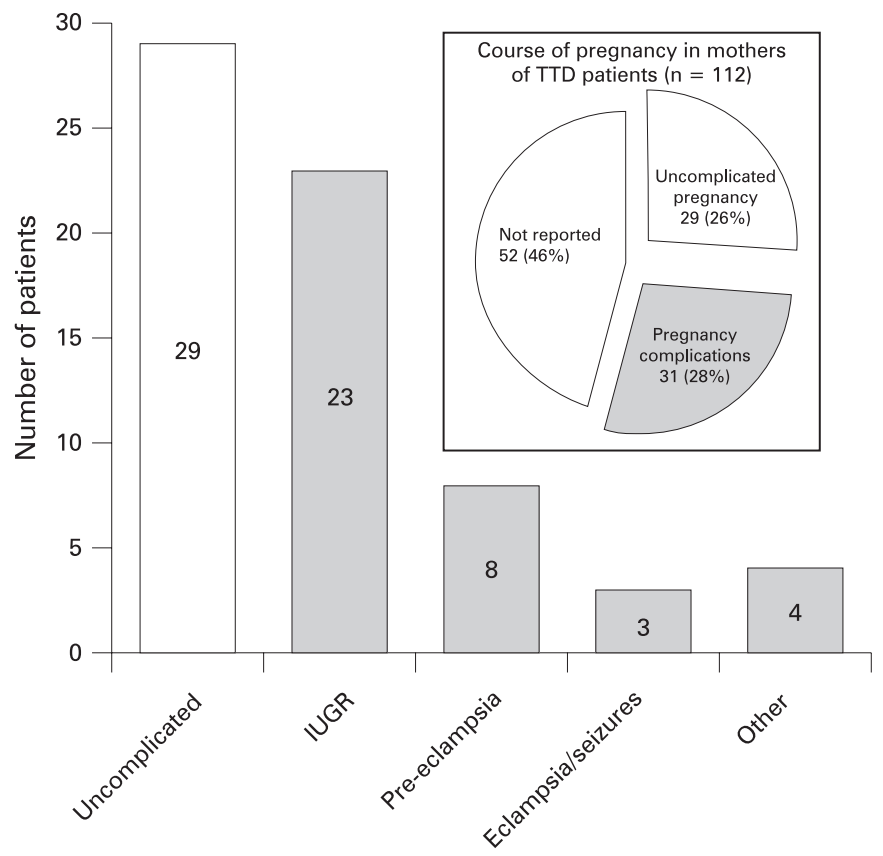

Pregnancy complications ( $n=60$ pregnancies)

Figure 6 Reported course of pregnancy in mothers delivering trichothiodystrophy (TTD) patients $(n=60)$. The number in each bar indicates the number of TTD pregnancies reported with the indicated pregnancy complication among the 60 pregnancies detailed in the reports. The pregnancies with complications are indicated with shaded bars. A pregnancy may have more than one complication reported. The inset shows the proportion of the 112 cases reporting pregnancy complications. The bar labelled "Other" refers to bleeding (2 patients), oligohydramnios (1), placental abnormalities (1). IUGR, intrauterine growth retardation.

age of reported patients with cataracts was 7.5 years, and all but one patient were $<25$ years old. Three patients ${ }^{15} 7099$ were reported to have surgery to correct their cataracts. Other ocular findings include nystagmus (14\%) and strabismus (10\%).

Infections were described in 51 patients (fig 3). Fourteen patients were described as having infections (especially respiratory infections) within the first year of life, including five in the neonatal period. Forty patients $(36 \%)$ had recurrent infections. Reported infections were most commonly respiratory (29\%), gastrointestinal $(13 \%)$, and ear (11\%). Recurrent urinary infections were reported in five patients, all starting younger than age 5 years. ${ }^{32} 66697383$ Aetiologies of infections included bacterial, fungal and viral. Two patients ${ }^{38} 91$ were reported to have hypogammaglobulinaemia, for which they both received intravenous immunoglobulin. One patient ${ }^{91}$ was reported to receive prophylactic trimethoprim-sulfamethoxazole, but was also the only patient reported to have combined immunodeficiency. Three patients ${ }^{41}$ with recurrent infections in childhood were reported in adolescence to no longer be prone to infections. In addition, patients were reported as having asthma or allergies

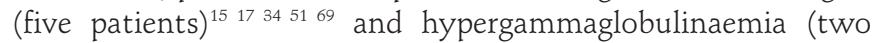
patients). ${ }^{5666}$ Thirteen patients ${ }^{40} 414663859091949899107$ died of infection, which mostly consisted of respiratory infection or sepsis. The immune system of one patient with combined immunodeficiency was studied in two papers. One found the patient to have defective dendritic cell maturation and the second found decreased $\mathrm{T}$ cell regulation repertoire complexity suggesting a possible $\mathrm{T}$ cell regulation abnormality. ${ }^{49} 91$

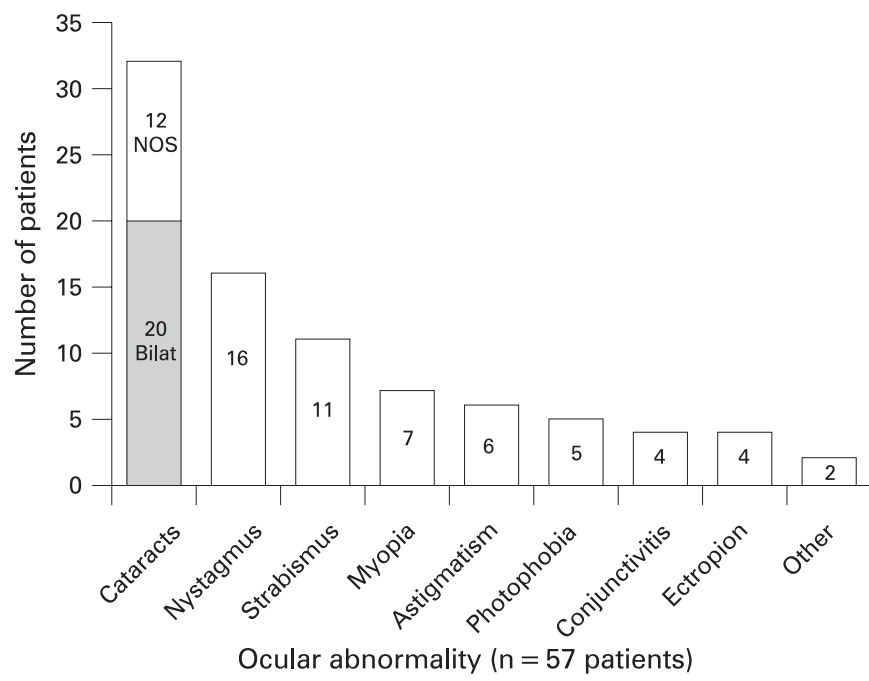

Figure 7 Ocular abnormalities reported $(n=57)$ in trichothiodystrophy (TTD) patients. The number in each bar indicates the number of TTD cases reported with the indicated ocular abnormality among the 57 patients detailed in the reports. "Bilat" in shaded bar-bilateral cataracts; of the 32 patients with cataracts, 20 were reported as bilatera and 8 as congenital. NOS — cataracts not otherwise specified. "Other" refers to dry eyes (1 patient) and retinal pigmentation (1). A patient may have more than one ocular abnormality reported.

\section{Skeletal and dental abnormalities}

Skeletal and dental findings are listed in table 7. All except on $e^{47}$ of these 46 patients also had neurologic abnormalities. Radiographic bone abnormalities were reported in 38\% patients. The most common findings were osteosclerosis (14\%), delayed bone age $(13 \%)$, and osteopenia (9\%). When specified, the osteosclerosis was usually axial, and the osteopenia distal. Four

Table 7 Skeletal and dental abnormalities $(n=46)$ in reported trichothiodystrophy patients

\begin{tabular}{|c|c|}
\hline & $\begin{array}{l}\text { Patients } \\
\text { No. }(\%)\end{array}$ \\
\hline Radiographic bone abnormality & $43(38)$ \\
\hline Osteosclerosis* & $16(14)$ \\
\hline Delayed bone age & $14(13)$ \\
\hline Osteopenia & $10(9)$ \\
\hline Kyphosis & $7(6)$ \\
\hline Coxa valga & $4(4)$ \\
\hline 0thert & $8(7)$ \\
\hline Joint abnormality & $15(13)$ \\
\hline Contractures: & $8(7)$ \\
\hline Joint dislocation & $4(4)$ \\
\hline Other§ & $7(6)$ \\
\hline Tooth abnormality & $23(21)$ \\
\hline Caries & $21(19)$ \\
\hline Enamel hypoplasia & $4(4)$ \\
\hline Other & $4(4)$ \\
\hline Normal teeth & $18(16)$ \\
\hline Normal or no skeletal or tooth abnormality reported & $66(59)$ \\
\hline Total & $112(100)$ \\
\hline \multicolumn{2}{|c|}{$\begin{array}{l}\text { *4 patients had both osteosclerosis and osteopenia. } \\
\text { †Pectus excavatum (3 patients), scoliosis (2), hallux valgus (2), } \\
\text { bilateral hammer toe deformities (2). } \\
\text { \$Contractures of hips and knees (3), and hands (3). } \\
\text { §Clinodactyly of 5th finger, short limbs, tapering fingers, syndactly } \\
\text { joint hypermobility. } \\
\text { ๑Dystrophic teeth (2) and hypoplastic teeth (enamel not specified) (2) }\end{array}$} \\
\hline
\end{tabular}


patients had both osteosclerosis and osteopenia. ${ }^{17} 5163106$ Seven additional patients were reported as having normal bone age, and no radiographic bone abnormalities.

The most common joint abnormalities were contractures (7\%) and joint dislocation (4\%). Contractures were of hip and knees (three patients) ${ }^{516982}$ and hands (three patients). ${ }^{5671} 103$ Subluxation was of the hip (three patients) ${ }^{5156} 114$ and toes (one patient). ${ }^{76}$ The most common tooth abnormality was caries (19\%). Eleven of these 21 patients had severe caries. ${ }^{13} 17224757586972767799$

\section{Cardiac and hepatic abnormalities}

In addition, cardiac defects were noted in eight patients and included cardiomyopathy, pulmonic stenosis and ventricular septal defect. ${ }^{22} 747585107$ Three additional patients were reported to have a murmur, but no cardiac defect was identified..$^{36} 6372$ Two patients ${ }^{85}$ were reported to have multiple liver haemangioendotheliomas.

\section{Haematologic abnormalities}

Haematologic abnormalities were reported in 24 patients (table 8). These findings consisted of anaemia (12\%), low mean corpuscular volume (MCV) $(9 \%)$, neutropenia (9\%), and elevated haemoglobin A2 (7\%). Two cases ${ }^{69} 76$ of anaemia were due to iron deficiency. Eight TTD patients ${ }^{111}$ with XPD mutations were reported as having "haematologic features of beta-thalassemia trait, and reduced levels of beta-globin synthesis and beta-globin mRNA". The cause of anaemia in the remaining three patients ${ }^{38} 5472$ was Coombs positive haemolytic anaemia, sideroblastic anaemia, and unspecified. Twenty-one per cent of patients had either a normal complete blood cell count $(\mathrm{CBC})$ or routine blood analysis.

\section{DNA repair abnormalities and gene defects}

DNA repair abnormalities or gene defects were reported in 41 patients. Thirty-two patients were reported as having mutations in XPD, two in XPB and two in TTDA (table 3, fig 4). Five patients, ${ }^{59} 80100108$ were reported to have cellular UV hypersensitivity, with no specific gene defect determined. Six additional patients $^{7}$ were reported as having mutations in the newly discovered TTDN1 gene with unknown function. Eleven patients were reported to not have a DNA repair abnorm-

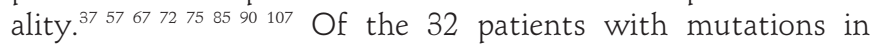
$\mathrm{XPD}, 27$ were reported to have photosensitivity. While most of the cases with a DNA repair abnormality were from patients with photosensitivity, this might be due to ascertainment bias in that photosensitivity is a reason to suspect a DNA repair abnormality. Genotype-phenotype correlation is best studied on a group of patients who are studied in the same manner. It

Table 8 Haematologic abnormalities reported $(n=24)$ in trichothiodystrophy patients

\begin{tabular}{lc}
\hline & $\begin{array}{c}\text { Patients } \\
\text { No. }(\%)\end{array}$ \\
\hline Haematologic abnormality & $24(21)$ \\
Anaemia* $^{*}$ & $13(12)$ \\
Low MCV & $10(9)$ \\
Neutropenia & $10(9)$ \\
Elevated haemoglobin A2 & $8(7)$ \\
Normal; not reported & $24(21) ; 64(57)$ \\
Total & $112(100)$ \\
\hline
\end{tabular}

MCV, mean corpuscular volume.

*Two patients reported with iron deficiency. may not be valid to compare phenotypes from reports with different extents of clinical information provided.

\section{DISCUSSION}

Birth abnormalities, pregnancy complications and increased mortality in TTD

TTD has substantial morbidity and mortality in the neonatal and childhood years. There was an approximately 20-fold increase in the probability of death in reported TTD children $\leqslant 10$ years of age compared to the US general population. This increased mortality in TTD is neither widely recognised nor well understood. However, there may be bias in reporting more severe cases, thereby suggesting a worse prognosis for TTD.

This study documents the wide spectrum of severity within TTD. The high frequencies of reported abnormal characteristics at birth and pregnancy abnormalities suggest that childhood and neonatal morbidity can begin in the prenatal period. Fiftythree per cent of reported patients had abnormal characteristics at birth and $28 \%$ of pregnancies were abnormal. The relatively young median parental ages (maternal: 25 years; paternal: 27 years) at birth of TTD patients indicates that advanced parental age was a not a factor in the frequency of pregnancy abnormalities or in the development of TTD. This surprisingly large number of reports of pregnancy abnormalities suggests that the pathophysiology of TTD involves a developmental abnormality directly affecting the pregnancy. This adds a complex dimension to understanding the clinical phenotype of TTD. Some of the clinical features may be due to the effect of TTD on the affected patient; in addition, some of the clinical disease may be secondary to compromise resulting from maternal pregnancy abnormality.

Different mutations in the $X P D$ or $X P B$ genes can lead to TTD, XP or a clinical overlap of both, the XP/TTD complex. Genes that are defective in TTD, XPB, XPD and TTDA, are components of the basal transcription factor, TFIIH, as well as the nucleotide excision repair pathway. ${ }^{5}{ }^{120}{ }^{121}$ A current theory suggests that mutations in these genes in patients with XP predominantly impede DNA repair, while mutations in the same genes in TTD patients predominantly affect transcription. ${ }^{121}$ Thus, XP is a disease of progressive sunlight induced degeneration of the skin. ${ }^{21}$ In contrast to XP, TTD is primarily a disorder of development which may be the consequence of transcriptional anomalies resulting from different defects in the same DNA repair genes. ${ }^{11}{ }^{120}$ Thus the finding of elevated haemoglobin A2 and low red blood cell MCV that mimic thalassaemia without a defect in a haemoglobin gene was interpreted as a transcription defect in TTD patients with mutations in the XPD gene. ${ }^{111}$ The other developmental features of TTD may represent abnormalities in transcription of genes that are essential for normal pregnancy and fetal development. The high frequency of reported fetal abnormalities and maternal pregnancy complications in mothers of TTD patients suggests a role of the DNA repair/transcription genes in normal pregnancy and fetal development. CS, another rare genetic disease with defective DNA repair, shares some of the same clinical features as TTD including photosensitivity, short stature, developmental delay, IUGR, dysmyelination of the brain, and an outgoing social personality. ${ }^{26}{ }^{122} \mathrm{CS}$ is caused by CSA and CSB genes, which have a role in repair of actively transcribing genes.

\section{Classification}

Trichothiodystrophy is a rare multisystem disorder with a wide spectrum of clinical involvement. We were able to identify only 
112 patients reported in the world's literature who fit our criteria for inclusion into this study of TTD reports. These criteria allowed us to capture a large number of TTD cases from the literature where limited information was available on each patient. These criteria were not intended to be used for diagnosis of new patients where more extensive evaluation should be possible. ${ }^{4}$ The goal of this study was to assess the frequency of clinical features in order to better understand the spectrum of manifestations of TTD. ${ }^{123}$ The most common clinical features were brittle hair or hair shaft abnormalities (96\%), intellectual impairment or developmental delay $(86 \%)$, short stature $(73 \%)$ and ichthyosis $(65 \%)$. While it is useful to look at the frequency of different features across the broad population of patients, it is also important to know how often a set of clinical features occurs together (fig 4). Sixty-four per cent of patients had the clinical features to fit into the category of either PIBI(D)S, IBI(D)S or BI(D)S; however, the others $(36 \%)$ did not. Almost all of the patients who had clinical features sufficient to fit into these designations had additional clinical manifestations not specified by the acronyms. In addition, even the broadest acronym, PIBIDS, does not include several major clinical features found to be more common than photosensitivity $(42 \%)$ and decreased fertility, including abnormal characteristics at birth (53\%), ocular abnormalities (51\%), and infections (46\%), which should be considered major clinical features of TTD. So these acronyms are poor descriptors of TTD patients' clinical manifestations.

Van Neste ${ }^{115}$ suggested a classification system in 1989 based on increasing severity beginning with only hair defects. While this schema takes into account additional features of TTD beyond PIBIDS, it intrinsically implies a sequential pattern to the progression of disease severity. As seen in fig 4, not all patients fit into a uniform sequence. For example, although the Van Neste classification lists photosensitivity as a more severe case of TTD, some patients may have photosensitivity without ichthyosis or short stature. Van Neste's classification was later expanded to include more features, such as chronic neutropenia or immunoglobulin deficiency, severe IUGR and basal ganglia calcifications. ${ }^{1}$

\section{Multiple reported abnormalities in TTD}

Surveys of reported clinical features have several weaknesses. These include ascertainment bias, leading to the reporting of patients who are more interesting and severe and the underrepresentation of more mildly affected patients. Reports vary with respect to thoroughness of clinical evaluation, leading to the probable underreporting of many features that may not have been evaluated. This suggests that the prevalence of many clinical features summarised here may under-represent their true frequencies. In addition, since we would expect milder phenotypes to be less likely to be reported, TTD may be much more common than the number of reported cases implies.

Neurologic abnormalities (86\%) were frequently reported in TTD cases, manifesting most commonly as developmental delay, intellectual impairment, microcephaly, impaired motor control or psychomotor retardation. This high frequency may be an underestimate, since 11 of the 16 patients who were not reported to have developmental delay or intellectual impairment were $<5$ years old. In general, these findings were not found to be deteriorations in neurologic status, but rather were more suggestive of a chronic non-progressive condition. Two exceptions were reported. One patient ${ }^{63}$ had progressive encephalopathy and ataxia and a second patient ${ }^{70}$ had developmental regression after an episode of measles. This further supports an early developmental abnormality being a key factor leading to TTD neurologic involvement. In contrast, about $20 \%$ of XP patients, who have different mutations in many of the same genes as TTD patients, ${ }^{121}$ have neurological abnormalities which manifest as progressive degeneration. ${ }^{29}$ Recent studies have looked at the relationship between DNA repair defects and impaired neurologic development. ${ }^{11}$ The presence of ichthyosis may be a marker of a systemic developmental abnormality since more than $90 \%$ of the TTD patients reported to have ichthyosis also have developmental delay.

Infections were commonly (46\%) reported and were often recurrent (36\%). Sixty-five per cent of the 20 reported deaths were related to infections. This frequency and severity of infections suggests that the pathophysiology of TTD includes an immunologic abnormality. However, no consistent laboratory abnormality in the immune system has been identified in TTD patients.

\section{TTD involves many medical specialties}

Effective management of the multisystem abnormalities of TTD involves a multidisciplinary approach involving many medical specialties. Seventy-seven per cent of patients were $\leqslant 14$ years old, and thus it is important for paediatricians to be aware of this disease. Sixty-three per cent of patients had abnormal characteristics at birth, signalling importance for the neonatologist. Twenty-three per cent were from abnormal pregnancies, which would bring these mothers to the attention of obstetricians. Twenty-nine per cent of patients had cataracts (median age 7.5 years), including eight with congenital cataracts, which, if undetected, can lead to vision impairment and interference with early childhood development and learning. The oldest TTD patient in the literature (47 years) was first seen by those researchers at age 17 with pruritis and urticaria. She also had symptoms in her first year of life, consisting of collodion baby, congenital hip subluxation, and psychomotor developmental delay. ${ }^{56}$

These patients may present to specialists in obstetrics, neonatology, paediatrics, ophthalmology, neurology, orthopaedics, internal medicine, rehabilitation medicine, immunology, infectious disease, haematology, genetics, or radiology in addition to dermatology. If properly aware, any of these specialists can make the diagnosis. Since prenatal diagnosis is possible, establishment of a diagnosis can identify the risk to future pregnancies. It is surprising that a disorder with such a broad range of multisystem abnormalities can be unified by the simple finding of tiger tailed banding under polarised microscopy. This very simple and inexpensive test can reliably establish a diagnosis in both the healthy adult with learning disabilities and the severely ill, collodion baby in the neonatal intensive care unit. This review characterises the wide spectrum of TTD and reinforces the importance of this simple screening test for patients with these multisystem findings. Greater recognition among a broad range of specialists can facilitate early diagnosis and treatment and identification of risk to future pregnancies.

Acknowledgements: This research was supported by the Intramural Research Program of the NIH, National Cancer Institute, Center for Cancer Research. We would like to thank Philip Rosenberg, PhD, Biostatistics Branch, Division of Cancer Epidemiology and Genetics, National Cancer Institute for assistance with the Kaplan Meier analysis and Melissa Meredith, MD, National Human Genome Research Institute for assistance in evaluation of obstetric information. Christine Liang, MD, made the photomicrographs of the TTD hairs while she was a Howard Hughes Medical Institute$\mathrm{NIH}$ Research Scholar in our laboratory. An abstract of this work was presented at the 68th Annual Meeting of the Society for Investigative Dermatology, May 2007. ${ }^{124}$

Competing interests: None. 


\section{REFERENCES}

1. Itin PH, Sarasin A, Pittelkow MR. Trichothiodystrophy: update on the sulfurdeficient brittle hair syndromes. J Am Acad Dermatol 2001;44:891-920.

2. Ruenger TM, DiGiovanna JJ, Kraemer KH. Hereditary Diseases of genome instability and DNA repair. In: Wolff K, Goldsmith LA, Katz SI, Gilchrest BA, Paller AS, Leffell DJ, editors.Fitzpatrick's dermatology in general medicine, 7 ed. New York: McGraw Hill, 2008:1311-25.

3. Liang C, Kraemer KH, Morris A, Schiffmann R, Price VH, Menefee E, DiGiovanna JJ. Characterization of tiger tail banding and hair shaft abnormalities in trichothiodystrophy. J Am Acad Dermatol 2005;52(2 Pt1):224-32.

4. Liang C, Morris A, Schlucker S, Imoto K, Price VH, Menefee E, Wincovitch SM, Levin IW, Tamura D, Strehle KR, Kraemer KH, DiGiovanna JJ. Structural and molecular hair abnormalities in trichothiodystrophy. J Invest Dermatol 2006;126:2210-6.

5. Friedberg EC, Walker GC, Siede W, Wood RD, Schultz RA, Ellenberger T. DNA repair and mutagenesis, 2 ed. Washington DC: ASM Press, 2006.

6. Kraemer KH, Ruenger TM. Genome instability, DNA repair and cancer. In: Wolff K, Goldsmith LA, Katz SI, Gilchrest BA, Paller AS, Leffell DJ, eds. Fitzpatrick's dermatology in general medicine, 7 ed. New York: McGraw Hill, 2008:977-86.

7. Nakabayashi K, Amann D, Ren Y, Saarialho-Kere U, Avidan N, Gentles S, MacDonald JR, Puffenberger EG, Christiano AM, Martinez-Mir A, Salas-Alanis JC, Rizzo R, Vamos E, Raams A, Les C, Seboun E, Jaspers NG, Beckmann JS, Jackson CE, Scherer SW. Identification of C7orf11 (TTDN1) gene mutations and genetic heterogeneity in nonphotosensitive trichothiodystrophy. Am J Hum Genet 2005:76:510-6.

8. Kraemer $\mathbf{K H}$, Lee MM, Scotto J. DNA repair protects against cutaneous and internal neoplasia: evidence from xeroderma pigmentosum. Carcinogenesis 1984;5:511-4.

9. Kraemer KH, Lee MM, Scotto J. Xeroderma pigmentosum. Cutaneous, ocular, and neurologic abnormalities in 830 published cases. Arch Dermatol 1987:123:241-50.

10. Kraemer KH, Lee MM, Andrews AD, Lambert WC. The role of sunlight and DNA repair in melanoma and nonmelanoma skin cancer. The xeroderma pigmentosum paradigm. Arch Dermatol 1994;130:1018-21.

11. Kraemer K, Patronas N, Schiffmann R, Brooks B, Tamura D, DiGiovanna J. Xeroderma pigmentosum, trichothiodystrophy and Cockayne syndrome: a complex genotype-phenotype relationship. Neuroscience 2007;145:1388-96.

12. Price VH. Strukturanomalien des Haarschaftes. In: Orfanos CE, ed. Haar und Haarkrankheiten. Stuttgart: Gustav Fischer Verlag, 1979:387-446.

13. Crovato F, Borrone C, Rebora A. Trichothiodystrophy-BIDS, IBIDS and PIBIDS? Br J Dermatol 1983; 108:247

14. Jorizzo JL, Crounse RG, Wheeler CE Jr. Lamellar ichthyosis, dwarfism, mental retardation, and hair shaft abnormalities. A link between the ichthyosis-associated and BIDS syndromes. J Am Acad Dermatol 1980;2:309-17.

15. Jorizzo JL, Atherton DJ, Crounse RG, Wells RS. Ichthyosis, brittle hair, impaired intelligence, decreased fertility and short stature (IBIDS syndrome). $\mathrm{Br} J$ Dermatol 1982;106:705-10.

16. Baden HP, Jackson CE, Weiss L, Jimbow K, Lee L, Kubilus J, Gold RJ. The physicochemical properties of hair in the BIDS syndrome. Am J Hum Genet 1976;28:514-21.

17. Price VH, Odom RB, Ward WH, Jones FT. Trichothiodystrophy: sulfur-deficient brittle hair as a marker for a neuroectodermal symptom complex. Arch Dermatol 1980;116:1375-84.

18. Lubchenco LO, Hansman C, Dressler M, Boyd E. Intrauterine growth as estimated from liveborn birth-weight data at 24 to 42 weeks of gestation. Pediatrics 1963;32:793-800.

19. Braun-Falco 0, Ring J, Butenandt 0, Selzle D, Landthaler M. [Ichthyosis vulgaris, growth retardation, hair dysplasia, tooth abnormalities, immunologic deficiencies, psychomotor retardation and resorption disorders. Case report of 2 siblings] Hautarzt 1981;32:67-74

20. Leupold D. [Ichthyosis congenita, cataract, mental retardation, ataxia, osteosclerosis and immunologic deficiency-a particular syndrome?]. Monatsschr Kinderheilkd 1979;127:307-8.

21. Salfeld K, Lindley MJ. [On the problem of combination of symptoms in ichthyosis vulgaris with bamboo hair formation and ectodermal dysplasia]. Dermatol Wochenschr 1963;147:118-28.

22. Pollitt RJ, Jenner FA, Davies M. Sibs with mental and physical retardation and trichorrhexis nodosa with abnormal amino acid composition of the hair. Arch Dis Child 1968:43:211-6.

23. Brown AC, Belser RB, Crounse RG, Wehr RF. A congenital hair defect: trichoschisis with alternating birefringence and low sulfur content. J Invest Dermatol 1970:54:496-509.

24. Tay CH. Ichthyosiform erythroderma, hair shaft abnormalities, and mental and growth retardation. A new recessive disorder. Arch Dermatol 1971:104:4-13.

25. Jackson CE, Weiss L, Watson JH. "Brittle" hair with short stature, intellectual impairment and decreased fertility: an autosomal recessive syndrome in an Amish kindred. Pediatrics 1974;54:201-7.

26. Happle R, Traupe $H$, Grobe H, Bonsmann G. The Tay syndrome(congenital ichthyosis with trichothiodystrophy). Eur J Pediatr 1984;141:147-52.

27. Arbisser Al, Scott Cl Jr, Howell RR, Ong PS, Cox HL Jr. A syndrome manifested by brittle hair with morphologic and biochemical abnormalities, developmental delay and normal stature. Birth Defects Orig Artic Ser 1976;12:219-28.
28. Howell RR, Arbisser Al, Parsons DS, Scott Cl, Fraustadt U, Collie WR, Marshall RN, Ibarra OC. The Sabinas syndrome. Am J Hum Genet 1981;33:957-67.

29. Happle R, Traupe H, Grobe H, Bonsmann G. Author's reply. Eur J Pediatr 1984;142:234.

30. Chapman S. The trichothiodystrophy syndrome of Pollitt. Pediatr Radiol 1988:18:154-6.

31. van Neste D, Caulier B, Thomas P, Vasseur F. PIBIDS: Tay's syndrome and xeroderma pigmentosum. J Am Acad Dermatol 1985:12(2 Pt 1):372-3.

32. Stefanini M, Lagomarsini P, Arlett CF, Marinoni S, Borrone C, Crovato F, Trevisan G, Cordone G, Nuzzo F. Xeroderma pigmentosum (complementation group D) mutation is present in patients affected by trichothiodystrophy with photosensitivity. Hum Genet 1986;74:107-12

33. Stefanini M, Vermeulen W, Weeda G, Giliani S, Nardo T, Mezzina M, Sarasin A, Harper JI, Arlett CF, Hoeijmakers JH. A new nucleotide-excision-repair gene associated with the disorder trichothiodystrophy. Am J Hum Genet 1993;53:817-21.

34. Vandenberghe K, Casteels I, Vandenbussche E, De Zegher F, De Boeck K. Bilateral cataract and high myopia in a child with trichothiodystrophy: a case report. Bull Soc Belge Ophtalmol 2001;282:15-8.

35. Giglia-Mari G, Coin F, Ranish JA, Hoogstraten D, Theil A, Wijgers N, Jaspers NG Raams A, Argentini M, van der Spek PJ, Botta E, Stefanini M, Egly JM, Aebersold R, Hoeijmakers JH, Vermeulen W. A new, tenth subunit of TFIIH is responsible for the DNA repair syndrome trichothiodystrophy group A. Nat Genet 2004;36:714-9.

36. Weeda G, Eveno E, Donker I, Vermeulen W, Chevallier-Lagente 0, Taieb A, Stary A, Hoeijmakers JH, Mezzina M, Sarasin A. A mutation in the XPB/ERCC3 DNA repair transcription gene, associated with trichothiodystrophy. Am J Hum Genet 1997;60:320-9.

37. Alfandari S, Delaporte E, van Neste D, Lucidarme-Delespierre E, Piette F, Bergoend H. A new case of isolated trichothiodystrophy. Dermatology 1993:186:197-200.

38. Baden HP, Katz A. Trichothiodystrophy without retardation: one patient exhibiting transient combined immunodeficiency syndrome. Pediatr Dermatol 1988;5:257-9.

39. Battistella PA, Peserico A. Central nervous system dysmyelination in PIBI(D)S syndrome: a further case. Childs Nerv Syst 1996;12:110-3.

40. Blomquist HK, Back O, Fagerlund M, Holmgren G, Stecksen-Blicks C. Tay or IBIDS syndrome. A case with growth and mental retardation, congenital ichthyosis and brittle hair. Acta Paediatr Scand 1991;80:1241-5

41. Botta E, Nardo T, Broughton BC, Marinoni S, Lehmann AR, Stefanini M. Analysis of mutations in the XPD gene in Italian patients with trichothiodystrophy: site of mutation correlates with repair deficiency, but gene dosage appears to determine clinical severity. Am J Hum Genet 1998;63:1036-48.

42. Bracun R, Hemmer W, Wolf-Abdolvahab S, Focke M, Botzi C, Killian W, Gotz M, Jarisch R. Diagnosis of trichothiodystrophy in 2 siblings. Dermatology 1997;194:74-6.

43. Broughton BC, Lehmann AR, Harcourt SA, Arlett CF, Sarasin A, Kleijer WJ, Beemer FA, Nairn R, Mitchell DL. Relationship between pyrimidine dimers, 6-4 photoproducts, repair synthesis and cell survival: studies using cells from patients with trichothiodystrophy. Mutat Res 1990;235:33-40.

44. Broughton BC, Steingrimsdottir H, Weber CA, Lehmann AR. Mutations in the xeroderma pigmentosum group D DNA repair/transcription gene in patients with trichothiodystrophy. Nat Genet 1994:7:189-94.

45. Broughton BC, Berneburg M, Fawcett H, Taylor EM, Arlett CF, Nardo T, Stefanin M, Menefee E, Price VH, Queille S, Sarasin A, Bohnert E, Krutmann J, Davidson R, Kraemer KH, Lehmann AR. Two individuals with features of both xeroderma pigmentosum and trichothiodystrophy highlight the complexity of the clinical outcomes of mutations in the XPD gene. Hum Mol Genet 2001:10:2539-47.

46. Brusasco A, Restano L. The typical 'tiger tail' pattern of the hair shaft in trichothiodystrophy may not be evident at birth. Arch Dermatol 1997;133:249.

47. Calvieri S, Rossi A, Amorosi B, Giustini S, Innocenzi D, Micali G, Rizzo R. Trichothiodystrophy: ultrastructural studies of two patients. Pediatr Dermatol 1993:10:111-6.

48. Calvieri S, Giustini S, Nini G. Trichothiodystrophy: 2 cases. In: Wilkinson DS, ed. Clinical dermatology: The CMD case collection. Stuttgart: Schattauer, 1987:65-6.

49. Cancrini C, Romiti ML, Di Cesare S, Angelini F, Gigliotti D, Livadiotti S, Bertini E, Rossi P, Racioppi L. Restriction in T-cell receptor repertoire in a patient affected by trichothiodystrophy and CD4+ lymphopenia. Scand J Immunol 2002:56:212-6.

50. Chen E, Cleaver JE, Weber CA, Packman S, Barkovich AJ, Koch TK, Williams ML, Golabi M, Price VH. Trichothiodystrophy: clinical spectrum, central nervous system imaging, and biochemical characterization of two siblings. J Invest Dermatol 1994;103(5 Suppl):154S-8S.

51. Civitelli R, McAlister WH, Teitelbaum SL, Whyte MP. Central osteosclerosis with ectodermal dysplasia: clinical, laboratory, radiologic, and histopathologic characterization with review of the literature. J Bone Miner Res 1989;4:863-75.

52. Coulter DL, Beals TF, Allen RJ. Neurotrichosis: hair-shaft abnormalities associated with neurological diseases. Dev Med Child Neurol 1982;24:634-44.

53. Crovato F, Borrone C, Rebora A. The Tay syndrome (congenital ichthyosis with trichothiodystrophy). Eur J Pediatr 1984;142:233-4.

54. Dahbi-Skali H, Benamar L, Benchikhi H, Lakhdar H, Pinel N. PIBIDS syndrome (trichothiodystrophy type F) and skin cancer: an exceptional association. Photodermatol Photoimmunol Photomed 2004;20:157-8.

55. de Prost Y, Lemaistre R, Dupre A. Trichothiodystrophie associee a une ichtyose et a un retard statural et psychomoteur. Ann Dermatol Venereol 1986;113:1016-7.

56. Feier V, Solovan C. [Trichothiodystrophy and hypereosinophilic syndrome, an unusual association]. Ann Dermatol Venereol 1994:121:151-5. 
57. Fois A, Balestri P, Calvieri S, Zampetti M, Giustini S, Stefanini M, Lagomarsini $P$. Trichothiodystrophy without photosensitivity. Biochemical, ultrastructural and DNA repair studies. Eur J Pediatr 1988;147:439-41.

58. Fortina AB, Alaibac M, Piaserico S, Peserico A. PIBI(D)S: clinical and molecular characterization of a new case. J Eur Acad Dermatol Venereol 2001;15:65-9.

59. Foulc P, Jumbou 0, David A, Sarasin A, Stalder JF. [Trichothiodystrophy: progresssive manifestations]. Ann Dermatol Venereol 1999;126:703-7.

60. Gillespie JM, Marshall RC, Rogers M. Trichothiodystrophy-biochemical and clinical studies. Australas J Dermatol 1988;29:85-93.

61. Gummer CL, Dawber RP. Trichothiodystrophy: an ultrastructural study of the hair follicle. Br J Dermatol 1985;113:273-80.

62. Hansen LK, Wulff K, Brandrup F. [Trichothiodystrophy. Hair examination as a diagnostic tool]. Ugeskr Laeger 1993;155:1949-52.

63. Hersh JH, Klein LR, Joyce MR, Hordinsky MK, Tsai MY, Paller A, Hyzer R, Zax RH. Trichothiodystrophy and associated anomalies: a ariant of SIBIDS or new symptom complex? Pediatr Dermatol 1993;10:117-22.

64. Hora RK, Murthy VS. Mental retardation, short stature and brittle hair (BIDS syndrome; hair brain syndrome). Indian J Pediatr 1996;63:117-20.

65. Hordinsky MK, Briden B, Berry SA. Friable hair, urea cycle dysfunction, and trichothiodystrophy. A new X-linked genodermatosis. Curr Probl Dermatol 1987; 17:52-60

66. Itin PH, Pittelkow MR. Trichothiodystrophy with chronic neutropenia and mild mental retardation. J Am Acad Dermatol 1991;24(2 Pt 2):356-8.

67. King MD, Gummer CL, Stephenson JB. Trichothiodystrophy-neurotrichocutaneous syndrome of Pollitt: a report of two unrelated cases. J Med Genet 1984;21:286-9.

68. Kleijer WJ, Beemer FA, Boom BW. Intermittent hair loss in a child with PIBI(D)S syndrome and trichothiodystrophy with defective DNA repair-xeroderma pigmentosum group D. Am J Med Genet 1994;52:227-30.

69. Kousseff BG, Esterly NB. Trichothiodystrophy, IBIDS syndrome or Tay syndrome? Birth Defects Orig Artic Ser 1988;24:169-81.

70. Lehmann AR, Arlett CF, Broughton BC, Harcourt SA, Steingrimsdottir H, Stefanini M, Malcolm A, Taylor R, Natarajan AT, Green S. Trichothiodystrophy, a human DNA repair disorder with heterogeneity in the cellular response to ultraviolet light. Cancer Res 1988:48:6090-6.

71. Lucky PA, Kirsch N, Lucky AW, Carter DM. Low-sulfur hair syndrome associated with UVB photosensitivity and testicular failure. J Am Acad Dermatol 1984;11(2 Pt 2):340-6

72. Lynch SA, de Berker D, Lehmann AR, Pollitt RJ, Reid MM, Lamb WH. Trichothiodystrophy with sideroblastic anaemia and developmental delay. Arch Dis Child 1995:73:249-51.

73. Malvehy J, Ferrando J, Soler J, Tuneu A, Ballesta F, Estrach T. Trichothiodystrophy associated with urologic malformation and primary hypercalciuria. Pediatr Dermatol 1997; 14:441-5.

74. Marinoni S, Gaeta G, Not T, Freschi P, Trevisan G, Briscik E, Giliani S. Early recognition of trichothiodystrophy with xeroderma pigmentation group $\mathrm{D}$ mutation in a collodion baby. In: Panconesi E, ed. Dermatology in Europe. Oxford: Blackwell Scientific, 1991:632-3

75. Mazereeuw-Hautier J, Pech JH, Heitz F, Bonafe JL. [Trichothiodystrophy and congenital heart disease in two sisters]. Ann Dermatol Venereol 2002;129 (10 Pt 1):1168-71

76. McCuaig C, Marcoux D, Rasmussen JE, Werner MM, Gentner NE. Trichothiodystrophy associated with photosensitivity, gonadal failure, and striking osteosclerosis. J Am Acad Dermatol 1993;28(5 Pt 2):820-6.

77. Meynadier J, Guillot B, Barneon G, Djian B, Levy A. [Trichothiodystrophy]. Ann Dermatol Venereol 1987;114:1529-36.

78. Milligan A, Fletcher A, Porter DI, Hutchinson PE. Trichothiodystrophy. Clin Exp Dermatol 1991;16:264-7.

79. Motley RJ, Finlay AY. A patient with Tay's syndrome. Pediatr Dermatol 1989;6:202-5

80. Murphy LA, Atherton DJ. Collodion baby, failure to thrive and frequent fever due to trichothiodystrophy syndrome. Br J Dermatol 2003:149(Suppl 64):71-86.

81. Murrin KL, Clarke DJ. Behavioural aspects of Pollitt syndrome: a 32-year follow-up of a case described by R. J. Pollitt and colleagues in 1968. J Intellect Disabil Res 2002;46(Pt 3):273-8.

82. Ostergaard JR, Christensen T. The central nervous system in Tay syndrome. Neuropediatrics 1996;27:326-30.

83. Peserico A, Battistella PA, Bertoli P. MRI of a very rare hereditary ectodermal dysplasia: PIBI(D)S. Neuroradiology 1992;34:316-7.

84. Peter C, Tomczok J, Hoting E, Behrendt H. Trichothiodystrophy without associated neuroectodermal defects. Br J Dermatol 1998;139:137-40.

85. Petrin JH, Meckler KA, Sybert VP. A new variant of trichothiodystrophy with recurrent infections, failure to thrive, and death. Pediatr Dermatol 1998;15:31-4.

86. Poissonnier M, Blanc A, Bat P. [Genetic counseling in a case of neuroectodermosis: Vera Price trichothiodystrophy. Brittle hair with reduced sulfur content]. J Genet Hum 1988;36:361-5.

87. Porto L, Weis R, Schulz C, Reichel P, Lanfermann H, Zanella FE. Tay's syndrome: MRI. Neuroradiology 2000;42:849-51.

88. Price Veal. Trichothiodystrophy: sulfur-deficient brittle hair. In: Brown AC CR, ed. Hair, trace elements and human illness. New York: Praeger Publishers, Inc, 1980.

89. Przedborski S, Ferster A, Goldman S, Wolter R, Song M, Tonnesen T, Pollitt RJ, Vamos E. Trichothiodystrophy, mental retardation, short stature, ataxia, and gonadal dysfunction in three Moroccan siblings. Am J Med Genet 1990:35:566-73.
90. Quintero RA, Morales WJ, Gilbert-Barness E, Claus J, Bornick PW, Allen MH, Ackerman J, Koussef B. In utero diagnosis of richothiodystrophy by endoscopicallyguided fetal eyebrow biopsy. Fetal Diagn Ther 2000;15:152-5.

91. Racioppi L, Cancrini C, Romiti ML, Angelini F, Di Cesare S, Bertini E, Livadiotti S, Gambarara MG, Matarese G, Lago PF, Stefanini M, Rossi P. Defective dendritic cell maturation in a child with nucleotide excision repair deficiency and CD4 lymphopenia. Clin Exp Immunol 2001;126:511-8.

92. Rebora A, Crovato F. The Tay syndrome. A reply to the author's reply. Eur J Pediatr 1984;143:76.

93. Rebora A, Guarrera M, Crovato F. Amino acid analysis in hair from PIBI(D)S syndrome. J Am Acad Dermatol 1986:15:109-11.

94. Rebora A, Crovato F. PIBI(D)S syndrome - trichothiodystrophy with xeroderma pigmentosum (group D) mutation. J Am Acad Dermatol 1987;16(5 Pt 1):940-7.

95. Rebora A, Crovato F. Trichothiodystrophy, xeroderma pigmentosum and PIBI(D)S syndrome. Hum Genet 1988;78:106-8.

96. Riou L, Zeng L, Chevallier-Lagente 0, Stary A, Nikaido O, Taieb A, Weeda G, Mezzina M, Sarasin A. The relative expression of mutated XPB genes results in xeroderma pigmentosum/Cockayne's syndrome or trichothiodystrophy cellular phenotypes. Hum Mol Genet 1999:8:1125-33.

97. Rizzo R, Pavone L, Micali G, Calvieri S, Di Gregorio L. Trichothiodystrophy: report of a new case with severe nervous system impairment. J Child Neurol 1992;7:300-3.

98. Sarasin A, Blanchet-Bardon C, Renault G, Lehmann A, Arlett C, Dumez Y. Prenata diagnosis in a subset of trichothiodystrophy patients defective in DNA repair. Br J Dermatol 1992;127:485-91.

99. Sass J0, Skladal D, Zelger B, Romani N, Utermann B. Trichothiodystrophy: quantification of cysteine in human hair and nails by application of sodium azidedependent oxidation to cysteic acid. Arch Dermatol Res 2004;296:188-91.

100. Savary JB, Vasseur F, Vinatier D, Manouvrier S, Thomas P, Deminatti MM. Prenatal diagnosis of PIBIDS. Prenat Diagn 1991;11:859-66.

101. Schepis C, Elia M, Siragusa M, Barbareschi M. A new case of trichothiodystrophy associated with autism, seizures, and mental retardation. Pediatr Dermatol 1997;14:125-8.

102. Stefanini M, Giliani S, Nardo T, Marinoni S, Nazzaro V, Rizzo R, Trevisan G. DNA repair investigations in nine Italian patients affected by trichothiodystrophy. Mutat Res 1992;273:119-25

103. Stefanini M, Lagomarsini P, Giliani S, Nardo T, Botta E, Peserico A, Kleijer WJ, Lehmann AR, Sarasin A. Genetic heterogeneity of the excision repair defect associated with trichothiodystrophy. Carcinogenesis 1993;14:1101-5.

104. Takayama K, Salazar EP, Broughton BC, Lehmann AR, Sarasin A, Thompson LH, Weber CA. Defects in the DNA repair and transcription gene ERCC2(XPD) in trichothiodystrophy. Am J Hum Genet 1996;58:263-70.

105. Takayama K, Danks DM, Salazar EP, Cleaver JE, Weber CA. DNA repair characteristics and mutations in the ERCC2 DNA repair and transcription gene in a trichothiodystrophy patient. Hum Mutat 1997;9:519-25.

106. Toelle SP, Valsangiacomo E, Boltshauser E. Trichothiodystrophy with severe cardiac and neurological involvement in two sisters. Eur J Pediatr 2001;160:728-31.

107. Tolmie JL, de Berker D, Dawber R, Galloway C, Gregory DW, Lehmann AR, McClure J. Pollitt RJ, Stephenson JB. Syndromes associated with trichothiodystrophy. Clin Dysmorphol 1994;3:1-14.

108. van Neste D, Bore P. [Trichothiodystrophy: a morphological and biochemical study]. Ann Dermatol Venereol 1983:110:409-17.

109. van Neste D, de Greef $H$, van Haute N, van Hee J, van der Maesen J, Taieb A Maleville J, Fontan D, Bakry N, Gillespie JM, Marshall RC. High-sulfur protein deficient human hair: clinical aspects and biochemical study of two unreported cases of a variant of trichothiodystrophy. In: Van Neste, ed. Trends in human hair and alopecia research. Dordrecht: Klaver Academic, 1989:195-206.

110. Vermeulen W, Rademakers S, Jaspers NG, Appeldoorn E, Raams A, Klein B, Kleijer WJ, Hansen LK, Hoeijmakers JH. A temperature-sensitive disorder in basal transcription and DNA repair in humans. Nat Genet 2001;27:299-303.

111. Viprakasit V, Gibbons RJ, Broughton BC, Tolmie JL, Brown D, Lunt P, Winter RM, Marinoni S, Stefanini M, Brueton L, Lehmann AR, Higgs DR. Mutations in the general transcription factor TFIIH result in beta-thalassaemia in individuals with trichothiodystrophy. Hum Mol Genet 2001;10:2797-802.

112. Wakeling EL, Cruwys M, Suri M, Brady AF, Aylett SE, Hall C. Central osteosclerosis with trichothiodystrophy. Pediatr Radiol 2004;34:541-6.

113. Wetzburger CL, Van Regemorter N, Szliwowski HB, Abramowicz MJ, Van Bogaert P. Gray matter heterotopia and acute necrotizing encephalopathy in trichothiodystrophy. Pediatr Neurol 1998;19:392-4.

114. Yoon HK, Sargent MA, Prendiville JS, Poskitt KJ. Cerebellar and cerebral atrophy in trichothiodystrophy. Pediatr Radiol 2005;35:1019-23.

115. van Neste D, Miller X, Bohnert E. Clinical symptoms associated with trichothiodystrophy: a review of the literature with special emphasis on light sensitivity and the association with xeroderma pigmentosum (complementation group D). In: Van Neste, ed. Trends in human hair and alopecia research. Dordrecht: Klaver Academic, 1989:183-93

116. Martin JA, Hamilton BE, Sutton PD, Ventura SJ, Menacker F, Kirmeyer S, Munson ML. Births: Final Data for 2005. National Vital Statistics Reports 2007:56:1-104.

117. Levin AV. Congenital eye anomalies. Pediatr Clin North Am 2003:50:55-76.

118. Alapetite C, Benoit A, Moustacchi E, Sarasin A. The comet assay as a repair test for prenatal diagnosis of Xeroderma pigmentosum and trichothiodystrophy. $J$ Invest Dermatol 1997:108:154-9. 
119. Savary JB, Vasseur F, Vinatier D, Manouvrier S, Deminatti MM. First-trimester prenatal exclusion of PIBIDS syndrome with normal DNA excision repair on chorionic villus cells. Prenat Diagn 1992;12:969-71.

120. Dubaele S, Proietti De SL, Bienstock RJ, Keriel A, Stefanini M, Van HB, Egly JM. Basal transcription defect discriminates between xeroderma pigmentosum and trichothiodystrophy in XPD patients. Mol Cell 2003;11:1635-46.

121. Lehmann AR. The xeroderma pigmentosum group D (XPD) gene: one gene, two functions, three diseases. Genes Dev 2001;15:15-23.
122. Rapin I, Lindenbaum Y, Dickson DW, Kraemer KH, Robbins JH. Cockayne syndrome and xeroderma pigmentosum. Neurology 2000;55:1442-9.

123. Itin PH, Pittelkow MR. Trichothiodystrophy: review of sulfur-deficient brittle hair syndromes and association with the ectodermal dysplasias. J Am Acad Dermatol 1990;22:705-17.

124. Faghri S, DiGiovanna JJ, Tamura D, Kraemer KH. Trichothiodystrophy includes a broad spectrum of multisystem abnormalities and may have a high mortality at a young age. J Invest Dermatol April 2007;127(Suppl 1):S106. 